\title{
Experience of people with advanced cancer faced with the impossibility of cure: a phenomenological analysis
}

Vivência de pessoas com câncer em estágio avançado ante a impossibilidade de cura: análise fenomenológica Vivencia de personas con cáncer en etapa avanzada ante la imposibilidad de la cura: un análisis fenomenológico

Eleandro do Prado ${ }^{1,2}$ (1) Catarina Aparecida Sales ${ }^{1}($ [ Nara Marilene Oliveira Girardon-Perlini ${ }^{3}[0$

Laura Misue Matsuda ${ }^{1}$ (D) Gabriella Michel dos Santos Benedetti ${ }^{1,4}$ (1) Sonia Silva Marcon ${ }^{1}$

${ }^{1}$ Universidade Estadual de Maringá, Programa de Pós-graduação em Enfermagem. Maringá, PR, Brasil.

2 Faculdade Guairacá. Guarapuava, PR, Brasil. ${ }^{3}$ Universidade Federal de Santa Maria, Programa de Pós-graduação em Enfermagem. Santa Maria, RS, Brasil.

${ }^{4}$ Universidade Estadual do Paraná. Paranavaí, PR, Brasil.
Corresponding author: Sonia Silva Marcon

E-mail: soniasilva.marcon@gmail.com

Submitted on 05/21/2019.

Accepted on 10/24/2019.

DOI: 10.1590/2177-9465-EAN-2019-0113

\begin{abstract}
Objective: To understand the experience of people with advanced-stage cancer given the impossibility of curing the disease. Method: A research based on the Heideggerian phenomenology conducted with 11 people with advanced-stage cancer. Data was collected between November 2015 and March 2016 through an open interview. Results: From the understanding of the reports, three themes emerged: Finding the inevitable possibility of death; Finding oneself through anguish and suffering; Seeking to transcend the existential anguish given the possibility of death. Conclusion and implications for practice: Experiencing incurability or re-experiencing cancer gives patients feelings of apprehension, fear, and frustration. However, suffering causes them to reflect on life and to set out on a new path, founded, above all, on spirituality. The need to accept the "Being" in its human totality is evident, considering its doubts and apprehensions, transcending its physical needs and entering into its biopsychosocial world.
\end{abstract}

Keywords: Neoplasms; Terminally ill; Life change events; Emotions; Attitude to death; Qualitative research.

\section{Resumo}

Objetivo: Compreender a vivência de pessoas com câncer em estágio avançado ante a impossibilidade de cura da doença. Método: Pesquisa embasada na fenomenologia heideggeriana realizada com 11 pessoas com câncer em estágio avançado. Os dados foram coletados entre novembro de 2015 e março de 2016 mediante entrevista aberta. Resultados: Da compreensão dos relatos, emergiram três temáticas: Encontrando-se com a possibilidade inevitável da morte; Encontrando-se consigo pela angústia e pelo sofrimento; Buscando transcender a angústia existencial ante a possibilidade da morte. Conclusão e Implicações para prática: Vivenciar a incurabilidade ou a re-experiência com câncer suscita nos doentes sentimentos de temor, medo e frustração. Contudo, o sofrimento os faz refletir sobre a vida e se dispor a trilhar um novo caminho, fundados, sobretudo, na espiritualidade. Evidencia-se a necessidade de acolher o "Ser" na sua totalidade humana, considerando suas dúvidas e apreensões, transcendendo as suas necessidades físicas e adentrando em seu mundo biopsicossocial.

Palavras-chave: Neoplasia; Doente Terminal, Experiência de vida; Sentimentos; Atitude frente a morte; Pesquisa qualitativa.

\section{Resumen}

Objetivo: Comprender la vivencia de personas con cáncer en etapa avanzada ante la imposibilidad de la cura. Método: Investigación basada en la fenomenología heideggeriana realizada con 11 personas con cáncer avanzado. Los datos se recopilaron entre noviembre de 2015 y marzo de 2016 a través de una entrevista abierta. Resultados: De la comprensión de los relatos, surgieron tres temáticas: Encontrarse con la posibilidad inevitable de la muerte; Encontrarse con la angustia y el sufrimiento; Buscar trascender la angustia existencial ante la posibilidad de la muerte. Conclusión e implicaciones para la práctica: Vivir la incurabilidad del cáncer o revivirlo suscita en los pacientes sentimientos de temor, miedo y frustración. Sin embargo, el sufrimiento los hace reflexionar sobre la vida y los dispone a recorrer un nuevo camino fundado, sobre todo, en la espiritualidad. Se evidencia la necesidad de acoger al "Ser" en su totalidad humana, considerando sus dudas y aprehensiones, trascendiendo sus necesidades físicas y adentrándose en su mundo biopsicosocial.

Palabras clave: Neoplasias; Enfermo terminal; Acontecimientos que cambian la vida; Emociones; Actitud frente a la muerte; Investigación cualitativa. 


\section{INTRODUCTION}

The prevalence of people with cancer has reached alarming numbers in recent decades, especially when the disease is at an advanced stage, consolidating its position as the second leading cause of death both in Brazil and worldwide. ${ }^{1}$ Just as the exponential growth of people with cancer occurs, there is in the field of science the development of increasingly effective research and therapeutic resources, with particular emphasis on healing events. ${ }^{2}$

Cancer is a complex and sometimes aggressive disease that, despite the outstanding scientific advances, its path may progress to a prognosis of incurability, that is, when all the prescribed possibilities to favor life are exhausted. Under these conditions the patient becomes permeated by a process where death becomes a very near possibility, almost noticeable by the patient outside of healing possibilities. ${ }^{2}$ Thus, any curative therapy instituted for the treatment may be considered futile and unresolvable, making the individual a being that walks irreversibly toward death. ${ }^{3}$

The finitude of life, however, is still fraught with yearnings and fears, which are accentuated when dealing with a chronic and incurable disease, such as cancer. In this context, experiencing incurability in oncology means that the disease has spread from its place of origin to vital organs and tissues, and the patient then sees death as an increasingly near horizon. ${ }^{4}$

To view this moment as a natural process and to be available to discuss openly about death, constitutes a possibility to transcend its existential plan before life, aiming at understanding the existence and, consequently, the meaning of dying.

In this sense, the literature stresses the importance of understanding the perceptions and needs of people who follow this path, in order to corroborate the construction of care that meets their needs and provides conditions for a quality of life and a good death, allowing them to who are in the process of terminality, not only die without suffering, but also express their feelings and needs in the face of death. ${ }^{5}$

In this context, the technical and cognitive components that involve the care given to people who are facing this condition are important, but the relational skills - which include attitudes and communication - of health professionals play a prominent role, as they directly reflect on the sick people, on their families and on their own team. ${ }^{6}$

Thus, this study confers the possibility of existential opening to address the impossibility of cure and death, allowing a space for people with advanced cancer to expose their feelings, without filters. This theme has already been evidenced as scarce in the literature, probably due to the difficulties in accessing the perceptions of this public, as well as the obstacles that these people have to express feelings and face the reality with which they are confronted..$^{2,7}$
Thus, giving a voice to people facing the pitfalls of a serious disease that cannot be cured is also a way to help them understand the path to death, but above all to give them the right to discuss the end of their own life. Thus, an authentic process of openness based on a comprehensive dialog with patients and family members is important and necessary in order to enable respect for their wishes and to avoid unnecessary suffering. ${ }^{8}$

Given the unknowns that perpetuate the experience of the impossibility of curing cancer and terminality, here is an important gap: need to deepen the understanding of the needs and meanings that emerge from this experience and that interfere in the life of these beings and the uniqueness of their existence.

When receiving this terminal prognosis, amid so many doubts, the question that remains is: "How many days do I have left?" but when living with people in these conditions, this answer I have never heard. From this, I came to realize that terminality is not about time, but about a serious disease that is progressing along its natural course, and that in many people it will produce a multitude of distinct feelings. This perception raised several concerns, especially one that guided the development of this study: How do people with advanced cancer experience the impossibility of curing their disease?

The theme explored here stems from a condensation of experiences, the result of years of practice with cancer patients, accompanying the discreet but present evolution of nursing care for those who experience the terminal process of life. Assisting people in these conditions leads me to reflect that cancer can be repeated in people without any distinction, but suffering is not unique, each person faces it in his own way and conceives it personally. This perspective began to instigate me and reflect on the individuality of each being and its conceptions in the terminality phase. Such concerns motivated the choice of the theme for this work, whose objective was to understand the experience of people with advanced cancer before the impossibility of cure of the disease.

\section{METHOD}

This is a qualitative study, based on Martin Heidegger's existential phenomenology. ${ }^{9}$ The choice of this methodology is justified by the possibility of approximation with the experience of people who live with the incurability of an oncological disease, considering their thinking, feeling and acting. It is understood that this methodological perspective enables the understanding of the perceptions and needs that involve people in the face of this reality. ${ }^{10}$

The protagonists of the study were people with advanced cancer disease, attended by a non-governmental institution located in a municipality in the northwest region of Paraná, Brazil, which is a reference for people with cancer in socially vulnerable situations. 
The institution offers outpatient health care, social support, as well as lodging, food and transportation to the treatment sites. The choice of this scenario was motivated by the various university extension projects developed there, which provide multi-professional care to patients and their families, especially those with advanced disease and with minimal possibilities of curative treatment.

Prior to initiating any research procedures, full compliance with the ethical issues established by Resolution 466 of the National Health Council was observed. The study was approved by the Standing Committee of Ethics in Research involving Human Beings of the State University of Maringá, under opinion No. 1,349,763.

The participants were pre-selected after consulting the users' permanence records provided by the institution. The condition of the advanced stage of the disease was identified from the record in the presence of metastasis, under palliative care or with closed prognosis and also by verbal information from the institution's employees. The inclusion criteria adopted were the following: diagnosis of incurability established more than six months ago (considering the feasibility of expressing the experience in their speeches), being aware of the diagnosis; being aware of the clinical stage of the disease, being followed-up at the institution at the time of data collection, and having their cognitive status preserved to answer questions, as assessed by the mental state mini-examination. ${ }^{11}$

Of the people who met the criteria defined in the study, 14 were contacted. At that time, they were informed about the objectives of the study, the importance of their collaboration, the commitment to confidentiality with which the data would be processed, and the right to suspend participation at any time in the study. Those who consented voluntarily to participate signed the Free and Informed Consent Form (FICF).

However, 11 people participated effectively in the study, considering that two of them did not meet the inclusion criteria, since they did not reach the minimum score in the assessment of preserved cognitive status and one died after the first contact.

The participants were approached and interviewed in meetings scheduled according to their availability, with a mean duration of 40 to 60 minutes. The meetings were held from November 2015 to March 2016, at their homes or at the institution with those who stayed there weekly. On average, three to four meetings were held with each participant. The interviews themselves were guided by the following guiding question: How has it been for you to live with the impossibility of curing your disease?

It is noteworthy that all meetings, after consent, were recorded on digital media. In addition, the following was also recorded: pauses, changes in the tone of the voice, cries, laughter and bodily manifestations such as the cracking of fingers, restless legs, lowering of eyes, among others, in order to enrich the description of the scene, and jointly with the speeches, compose the corpus of the analysis.
In the analysis, all the interviews were transcribed in full and afterwards read carefully, so that no relevant information was disregarded. On this occasion, the interviews were also enriched with information contained in the field diary, regarding the events and impressions of the researcher during their execution.

The analytical moment sought the facts that usually individuals do not readily disclose but are essential for understanding the phenomenon. ${ }^{12}$ To capture the fullness of meaning expressed by participants, the recommended steps were followed. ${ }^{13}$ Thus, in the first moment, we opted for the particular interpretation of each interview, starting from a path that reveals the ontic until the reach of the ontological dimension of people with advanced cancer, given the impossibility of curing their disease. To this end, the starting point was a free understanding of predefined concepts, to understand the daily facts revealed by the participants, without making any previous judgments or adopting opinions that could transgress such perception. ${ }^{12}$

The second moment, called interpretative comprehension, aimed to uncover the phenomena still hidden in the languages, from the interpretation of their meanings, that is, to reveal the individual's way of being when confronted with the revealed phenomena, which is interpreted and culminates in the Heideggerian hermeneutics. ${ }^{12}$ After the analyses, the ontological units were displayed, interpreted according to the Heideggerian precepts and with concepts and reflections submitted by other authors when addressing the same theme.

To preserve the anonymity of the participants, they were identified with character names from the book "The Little Prince," a timeless work of children's literature. ${ }^{14}$ In this work, one can identify a vast thematic content, involving interpersonal relationship, existence and criticism about the importance that subjects attach to material values. There it is reported that the child explicitly demonstrates what they feel, caring about what is essential.

\section{RESULTS}

The results of this study were the data from analyzing interviews of 11 people with advanced cancer who experienced the impossibility of curing the disease, whose ages ranged from 40 to 82 years old, eight of them female. The time elapsed from the first diagnosis ranged from 1 to 21 years. The discovery of the second outbreak of the disease was experienced by eight people, and the time since metastasis identification ranged from seven months to four years. The other three patients were diagnosed with the disease already clinically advanced.

The location of the primary cancer ranged from breast (four cases); lung (two cases); and oral cavity (two cases); to stomach, esophagus and skin (one case each). Metastases affected the lung (two cases); the Central Nervous System (CNS) (two cases); bone, colon and rectum, stomach and lymphoma (one case each). 
Regarding the treatment, ten patients reported at least one of the antineoplastic therapies (chemotherapy, radiotherapy and surgery). For one of the participants, given the aggressiveness of the disease, none of these treatments were prescribed.

From the testimonies, the perceptions and needs that involve people with advanced cancer were identified, given the impossibility of curing the disease, and unveiled the thematic units that represent the points of view of the studied phenomenon, which reflect how the participants of the study express their perspectives and experiences facing the incurability of their disease and facticity of death itself, while immersed in this reality.

These perspectives were aligned in the following ontological thematic units: Meeting the inevitable possibility of death; Meeting oneself through anguish and suffering; Seeking to transcend existential anguish given the possibility of death.

\section{Meeting the inevitable possibility of death}

This thematic unit expresses the path taken by the deponents from the moment they were diagnosed with cancer. At this moment, they expose the ills of the impact caused by this news.

We get pretty shaken because it's horrible. Because we think that this never happens to us. Then, when it happens, we get upset, and there's no way. Oh, I suffered a lot! I was very desperate [...] (Vain).

At this time there is not much to do, not much to run [...] when it comes to this (cancer), we know it's pain, suffering and death. This is how we think, this is how we think at first (Businesswoman).

When it happened (the diagnosis) it was difficult, because it is something that has no cure, we were waiting for what? Waiting for death [...] (Lampion Lighter).

When perceived with cancer, the person feels sentenced to death and suffering. Taboos and stigmas rooted in daily life are overwhelmed when the diagnosis is accompanied by treatment considered painful and fraught with painful consequences. In practice, many of the feelings that permeate one's life when faced with cancer, such as helplessness, hopelessness, fear, turn into suffering on the arduous path of an uncertain future.

It's a lot of suffering, it's a lot of pain, and it's a lot of bad things that happen in our bodies. If we didn't get in pain, didn't get so many things, maybe it would be easier (Vain).
In this sense, the deponents also exposed the impact of feeling in the body the known stigmas of the disease, expressed in feelings of anguish and frustration at the weakness of the treatment failure and aggressiveness of the disease, especially when metastasis in other organs was discovered.

The first one was in the lung, it was already a little scary, now this one in the brain, oh I was a little panicked, more thoughtful, more anxious, more nervous, more afraid (Aviator).

The impact of this was worse, it was stronger, because I was treating, I was consulting, and I was taking a drug, all these precautions so that I would not come back later, but suddenly he (doctor) said that I had metastasis. So I thought, how in all these exam months could you not see the business starting at the very beginning? How, if I followed and did everything? How did you let it take over the whole lung again? That was my thought (The Rose).

Thus, in view of the impossibility to cure the cancer, the patients began to see death as a real possibility and their life abbreviated by the disease that was at an advanced stage.

\section{Meeting oneself through anguish and suffering;}

In this ontological theme it is verified that the experience of cancer brings with it unpleasant symptoms and suffering, which substantially hinders people's daily lives. It is also observed that facing the disease and approaching death lead them to reflect on their own life, its existence and its future.

The disease has no cure (emphasis)! But, if I get along well with it, that's all that matters, living well, and preparing, praying, trying my best to do good for someone, did you understood? (Aviator).

Ah! So, I spoke for myself, now I am going to die, it's the end. But then I started to think, to reason. Oh, not quite like this! To die? Everybody will die. So, I didn't bow my head, I won't give in (Lampion Lighter).

Thus, people strengthen themselves and tolerate the fact that the cure of their disease is no longer feasible, accepting for themselves the fact that death is to come.

I think: Whatever I have to pass through, someone else doesn't. It's something we can't avoid, it's something from everyone. An illness, one can take medicine and heal, but death cannot. It's something we have to keep on waiting for. It's something we know will happen and we have to get used to it (Fox). 
Certainly, experiencing the impossibility of curing a disease gives rise to sadness and suffering in the face of the near-end possibility, however it can also present itself as an opportunity for learning and reframing values.

\section{Seeking in faith the hope to live before the possibility of death}

In the aggravation of the disease, the spiritual dimension gives opportunity to the development of hope as a purpose and meaning for life, favoring a positive look at coping with the situation.

Although they recognize the possibility of death itself; the physical well-being and spiritual faith of the participants reveal the hope for the impossible: healing, as they manifest a transient state of the lived reality. For these people, healing proves to be a palpable reality, even in their deepest yearnings. In a way, they mask the pain of the soul and the suffering of death in the miraculous possibility of healing, supported by the physical well-being they experience at that moment.

I have faith! It was the doctor who said that this (cancer) has no cure, but it was not God who spoke, and for God nothing is impossible. True, how many people who are misguided and have that strong faith, and end up surprising everyone (Vain).

Even with this disease, I already feel healed. Although this disease and treatment have a lot of effect, I still take the drugs and have a lot of faith in God, I'm in God's hands (Astronomer)

I believe that with the treatment it (the cancer) ceased.I believe so! I had a lot of faith in them (health team). Yeah, I think so! When l'm fine, I don't seem to have anything sick (Aviator).

Faced with the ambivalence of fear of death and hope for recovery, faith in treatment and God springs forth as a facilitating element, which helps the sick to accept the facticity that came to them in the form of the impossibility of curing the cancer.

\section{DISCUSSION}

Being-in-the-world puts man before all the situations that this condition can give him, whether they are suffering or pleasure, because the reality of being-in-the-world is being thrown into temporality. It is therefore a condition which makes him vulnerable to all the wonders and joys which they may bring him, but which does not exclude the obstacles and embarrassments that come from him, ${ }^{15}$ by experiencing, for example, the "pain" that cancer brings and its onset.

In its turn, man's way of being in the world is termed as Dasein, which means being-there. ${ }^{9}$ In the second section of the treatise on Being and Time, the Heideggerian reflections explain Dasein as Being-in-the-world existing in the world, inevitably becoming a Being-to-death. Nevertheless, the Dasein in its daily life thinks of death as something colloquial that is far from itself.
However, becoming aware of being a Being to death makes the Dasein distressed and fearful. In Heidegger's thought, fear is characterized as an improper disposition, for it finds its opportunity in what is approaching and brings with it the sensation of "malum futurum". $9 ; 16$ The existential and temporal meaning of fear is established in the form of self-forgetfulness. Thus, it is learned that the proximity to cancer, revealed in the first diagnosis, metastasis or recurrence, reveals thoughts of horror, dread and non-acceptance. However, this perception is accentuated in cases of relapse, when the hope of cure is still present. Given the circumvision of the facts the Being comes closer to its finitude. ${ }^{7}$

This thinking corroborates what is stated by other authors, ${ }^{7,17}$ that by experiencing the reality of a serious illness and facing a concrete possibility of death, the Being unveils, in addition to the fear and expectation of being in the world with a serious illness, still unexplored feelings, providing changes in the relationship with yourself and others. ${ }^{17}$

In fear, the Being-there is disturbed by the ending world, becoming afflicted and troubled, fearing the approach of something once so distant and now present in his life, that is, death. ${ }^{9}$ Thus, the discovery of a cancer diagnosis with an unfavorable prognosis causes the confrontation of man with his real condition of "Being-to-death". This is because human existence becomes the target of questions in various contexts, especially when the Being-there experiences a certain experience difficult to overcome or elaborate, causing fear, fear and anguish. ${ }^{8}$ In this understanding, the facticity of death can be perceived in the statements of the deponents, in the parallel between being with cancer and the incurability of the disease. And this reality transports them into nothingness, that is, simply waiting for death to come, death is brought/ anticipated by cancer.

The impact of the confirmation of having advanced cancer, regardless of its location and of being the first diagnosis or recurrence, initially aroused in the deponents feelings of pain, despair and surprise in the face of the lived reality, which is now imposed concretely on them.

Such evidence allows us to assert that almost as terrible as being diagnosed with cancer is the fact that they feel in their bodies the presence of an unwanted entity invading their existential dwelling, revealing that their living is threatened, and the continuity of their existence becomes an unknown. This endof-life view is steeped in the minds of most people who are faced with the diagnosis of cancer. ${ }^{18}$

Thus, when faced with the cancer illness, the "Being-sick" realizes that their future is under threat. It experiences feelings of anguish and anxiety, which come from the perception that "having cancer" causes a rupture in its existence, delineating the division between life before cancer and life with cancer. In this context, it is anticipated that the painful thing is not "having cancer", but to die "because-of-cancer". 
In this interpellation, the deponents also revealed that "having cancer" suddenly sends them to feelings of loss, especially at the stage when the disease worsens and the possibilities of cure become unlikely. Another study on the finitude of life and carried out with this same approach, emphasizes that, at this moment, the person succumbs to their own existential anguish and goes from author of their story to spectator of their life, having their dreams and autonomy taken from their hands. ${ }^{19}$

The Heideggerian ideas in the second section of Being and Time allude that upon discovering that it is a finite Being, the Being-there falls into a state of decay and becomes distressed before the world. To the philosopher, anguish "is not a negative sensation or condition; it is a fundamental disposition of a human being that brings him closer to his precarious and provisional condition". ${ }^{16 ; 20}$ But if, on the one hand, anguish causes the Being to fall before itself, it also causes it to transcend itself by taking its existence into its hands, that is, living authentically their Being-thrown-into-the-world. ${ }^{8}$

Facticity and decay are components that constitute inauthentic existence. Existential facticity, that is, being thrown into the world is an involuntary condition of man, since being in the world has no choice between happiness or suffering, as the experiences occur independently of his desire.

"Only in the anguish remains the possibility of a privileged opening to the extent that it singularizes. This singularization removes the being-there from its decay, and reveals its authenticity and inauthenticity as possibilities of its being". ${ }^{21}$

In the same molds and from the reports, it is clear that the deponents had no choice. When caught by cancer, they needed to learn to live and, above all, to transcend suffering, not being able to enjoy the choice between having or not having, or between life and death. Thus, when attentive to the possibility of their own death, the deponents reflect on their wills and perceptions, seeking a new way of living and thus highlight the hope for healing and life.

In this sense, the Being-there opens to itself its own being, and this opening eliminates obstructions, cover-ups, obscurations and shows itself. ${ }^{8}$ In this showing its clarity, people reveal themselves as Being-with, assuming the severe and limiting disease, recognizing the condition of incurability that the disease imposes on them.

From then on, man, being a Being-to-death, safeguarded the possibility of constructing his finite and unique historicity, since he only understands his own Being when facing the impossibility of Being. ${ }^{9}$ Thus, when attentive to the possibility of their own death, the deponents reflect on their wills and perceptions, seeking a new way of living and thus highlight the hope for healing and life.
When its own world is revealed, the Being-there, in its own way, unveils its own Being. ${ }^{16}$ This revelation of the world and the unveiling of the Being-there are consummated with a clearing of what is hidden and obscure, and with an elucidation of the disguises with which the Being-there obstructs its own mode of being.9;16

In this way, by gathering strength in suffering and being motivated by its beliefs, the Being seeks to rescue its autonomy and dignity to resume its role, to rise, to reconstruct itself and, thus, to continue on its path.

It is noticed that in the experience of living with the suffering of having cancer in an advanced stage, the deponents had the opportunity to look at themselves as a possible Being of their uniqueness, assuming their power-being and the responsibility of their launcher in the world. The emerging resilience seems to have served as an impulse, so that through it the deponents could face the possibility of death, assuming it as an integral part of their human process. Since man is a being-of-possibilities, he can rise from the condition of anguish and find his authentic existence, and thus takes the direction of his path with a view to achieving his purposes. In this way, anguish as emotion ahead of an event is able to arouse man from everyday stagnation, leading him to assume his way of being and to meet himself. ${ }^{10}$ On this point, Heidegger mentions that it is in the disposition of anguish that the phenomenon of death unfolds to the Being-there in an original and penetrating way. ${ }^{16}$

Anguish makes man a unique being: a being-in-the-world who, in the Heideggerian understanding, throws himself essentially to countless possibilities. As you understand the specifics of your existence, you can make choices that are more consistent with the purpose of your existence, reflecting on characteristics that propagate in time, plurality, singularity, moment, and condition in your life. ${ }^{16}$

Enabling reflections on his own death is another unique condition facilitated by the Heideggerian framework, especially when it comes to understanding the Dasein possibility, that is, to envision death as a natural and inherent process in life itself. ${ }^{22}$

This moment of being in the world, however, is softened by the hope of healing that is deposited in treatment, even though it is not favorable, combined with spirituality, which now becomes the faithful companion of those who walk through the darkness of cancer. ${ }^{23}$ These people seek relief from pain and the suffering of death in the miraculous possibility of healing, supported by faith in the impossible and the physical well-being in which they remain at the moment. With this thinking, the reality of incurability of the disease is succumbed, and people report keeping alive the hope that they will still find the cure and with it the inexorability of life dissipates.

Such perspectives denote some difficulty in understanding the situation of proximity to/with death or even escape from this truth that is found in its existence, showing that the experience of death becomes inauthentic, in which constantly the privilege of being-more-self power it is covered and thus the person internally dies symbolically. ${ }^{22}$ 
In the Heideggerian analysis, the Being-there covers for itself a Being-to-death fleeing from this unique truth in its existence. For the philosopher, it is that being-in-the-world actually dies, even though most of the time it does so in the mode of decay. "In this decaying being-with-to, the flight of strangeness is announced, that is, a more proper being-to-death". 9:32

However, the thread of hope placed in the faith shows that spirituality is also a source of support and comfort in the various stages of the disease, especially in the period of life threatening. Therefore, for people who live with the impossibility of curing a disease, faith is an important foundation of protection, which strengthens and nourishes them, providing support and hope, as well as peace and comfort, which helps them to accept the approach of their finitude..$^{23,24}$

It is important to highlight that, although spirituality and faith in a higher Being soften the impact of the aggravation of the disease, the suffering to be faced with the situation that impossibility for cure does exist. However, the power emanating from faith seems to rescue people from the murky waters that disease and hopelessness with life put them to navigate, providing them with the strength to emerge from this anguish and to glimpse possibilities.

\section{CONCLUSIONS AND IMPLICATIONS FOR PRACTICE}

Entering into the world of people with advanced cancer with no cure possibilities made it possible not only to glimpse the fragile human being, but to understand this Being in its temporal existentiality. Faced with these conditions, the sick Being-there manifests its way of being-with in this situation, because as a being of possibilities, it reveals to the ones around it the vastness of feelings that affect it: joys, pains and, especially, the needs that encompass their ontic-ontological priorities. The Heideggerian existential phenomenological analysis made it possible to understand the deponents' experiences in the face of such reality. For them, having cancer aroused feelings of apprehension and fear of the unknown, but experiencing the impossibility of curing advanced cancer produced even more overwhelming feelings, such as failure and disappointment.

Amid all the anxieties raised by terminality and for some moments, the anguish experienced enabled these people to take a new look at life, reflecting on a new way for facing their facticity. In such a way, the individuals presented themselves at times authentically, seeking ways to make their departure meaningful and at times inauthentic, bowing to possibilities for being healed.

Thus, through this study, it was understood that, in being ill, people start to live with the mist of death in their daily lives. And at this moment in their lives they try to rescue their vitality in every way, especially through faith. In this context, it was possible to embrace the importance of the spiritual dimension in the path of these people, re-signifying each moment and the experiences lived in overcoming pain and suffering.
The results submitted in this study do not apply generally, since it focused on the phenomenological understanding of the experiences of people with cancer, particularly at an advanced stage. Thus, one of its possible limitations is the time frame in which the participants were interviewed, that is, the inclusion of people with distinct and unique trajectories regarding the time of the disease may have influenced different perspectives and perspectives on their understanding of life and death.

In any case, it is noteworthy that the study made it possible to give the participants a voice to openly expose their experiences regarding such a unique moment in their lives. Thus, the results outlined herein contribute to an important gap evidenced in the literature, which is the approach of people who experience the death and dying process, as well as the death theme in nursing.

Finally, it is hoped that this study will encourage research studies that consider the inclusion of participants with similar illness trajectories and that take into consideration and complexity that revolves around the experience of people who have an incurable disease.

\section{FINANCIAL SUPPORT}

"This study was financed in part by the Coordenação de Aperfeiçoamento de Pessoal de Nível Superior - Brasil (CAPES) - Finance Code 001", through scholarship to Eleandro do Prado in the year of 2015 .

\section{AUTHORS' CONTRIBUTIONS}

Study design, acquisition, data analysis and outcome interpretation. Critical review of the manuscript. Approving the final version of the article. Responsibility for all aspects of the content and integrity of the published article. Eleandro do Prado.

Study design. Data analysis and outcome interpretation. Critical review of the manuscript. Approving the final version of the article. Responsibility for all aspects of the content and integrity of the published article. Catarina Aparecida Sales. Sonia Silva Marcon

Critical review of the manuscript. Approving the final version of the article. Responsibility for all aspects of the content and integrity of the published article. Nara Marilene Oliveira Giardon-Perlini. Laura Missue Matsuda. Gabriella Michel dos Santos Benedetti.

\section{ASSOCIATE EDITOR}

Antonio José Almeida Filho

\section{REFERENCES}

1. Faguet GB. A brief history of cancer: age-old milestones underlying our current knowledge database. Int J Cancer [Internet]. 2015 May; [Cited 2016 Set 24]; 136(9):2022-36. Available from: https://doi.org/10.1002/ ijc. 29134 
2. Capello EMCS, Velosa MVM, Salotti SRA, Guimarães HCQP. Confrontation of cancer patients and their family/caregivers facing life terminality. J Health Sci Inst [Internet]. 2012 Mar; [Cited 2016 Set 24]; 30(3):235-40. Available from: https://www.unip.br/presencial/comunicacao/publicacoes/ics/edicoes/2012/03_jul-set/ V30_n3_2012_p235a240.pdf

3. Costa EO, Batista PSS, Silva JCMC, Lima DRA, Farias PF, Bezerra AHM, Oliveira LRFA. Palliative care in the process of human terminality: Integrative review. International Archives of Medicine Section [Internet]. 2017 Apr; [Cited 2018 Jan 07]; 10(126): 1-11. Available from: https:// doi.org/10.3823/2396

4. Hui D, Santos R, Chisholm G, Bensal S, Crovador CS, Bruera E. Bedside clinical signs associated with impending death in patients with advanced cancer: Preliminary findings of a prospective, longitudinal cohort study. Câncer [Internet]. 2015 Mar; [Cited 2016 Out 22]; 121(6):960-7. Available from: https://doi.org/10.1002/cncr.29048

5. Silva RS, Pereira A, Mussi FC. Comfort for a good death: perspective nursing staff's of intensive care. Esc. Anna Nery [Internet]. 2015 Jan-Mar. [Cited 2016 Out 24]. 19(1):40-6. Available from: http://dx.doi. org/10.5935/1414-8145.20150006

6. Daronco VF, Rosanelli CLSP, Loro MM, Kolankiewicz ACB. Palliative care to cancer patients: perceptions of a nursing team. Cienc. Cuid. Saúde [Internet]. 2014 Out/Dez; [Cited 2016 Out 24]; 13(4):6557-664. Available from: http://dx.doi.org/10.4025/cienccuidsaude.v13i4.19146

7. Coropes VBAS, Valente GSC, Oliveira ACF, Paula CL, Souza CQS, Camacho ACLF. Opinion of terminal cancer patients on nursing assistance: Integrative review. Rev enferm UFPE on line. [Internet]. 2016 Dez. [Cited 2018 Jan 07];10(6):4927-33. Available from: https:// doi.org/10.5205/1981-8963-v10i6a11274p4927-4933-2016

8. Vasques TCS, Lunardi VL, Silva PA da, Carvalho KK, Lunardi Filho WD, Barros EJL. Perception of nursing professionals about patient care of the terminally ill in the hospital environment. Texto Contexto Enferm. [Internet]. 2016 Set; [Cited 2016 Out 26]; 25(3). Available from: http:// dx.doi.org/10.1590/0104-07072016000480014

9. Heidegger M. Ser e tempo. $6^{\mathrm{a}}$ ed. Petrópolis (RJ): Vozes; 2012.

10. Seboldi LF, Carraro TE. The authenticity of the being nursing-professor in the nursing care teaching practice: a heideggerian hermeneutics. Texto Contexto Enferm. [Internet]. 2013 Jan-Mar; [Cited 2016 Out 18]; 22(1):22-8. Available from: http://dx.doi.org/10.1590/S010407072013000100003

11. Melo MD, Barbosa, AJG. O uso do Mini-Exame do Estado Mental em pesquisas com idosos no Brasil: uma revisão sistemática. Ciênc. saúde coletiva [Internet]. 2015 Dez; [Cited 2016 Out 15]; 20(12): 3865-3876. Available from: http://dx.doi.org/10.1590/1413812320152012.06032015

12. Wakiuchi J, Marcon SS, Sales CA. Atenção a pacientes oncológicos na Estratégia Saúde da Família: olhar do usuário. Rev. Gaúcha Enferm. [Internet]. 2016; [Cited 2019 out 07]; 37 (1): e54088. Available from: http://dx.doi.org/10.1590/1983-1447.2016.01.54088
13. Paula CC, Souza IEO, Cabral IE, Padoin SMM. Analytical movement - Heideggerian hermeneutics: methodological possibility for nursing research. Acta paul. enferm. [Internet]. 2012 Dez; [Cited 2018 Jan 07];25(6):984-989. Available from: http://dx.doi.org/10.1590/S010321002012000600025

14. Exupéry AS. O Pequeno Príncipe. $51^{\underline{a}}$ ed. São Paulo (SP): Geração Editora; 2015.

15. Almeida CSL, Sales CA, Marcon SS. The existence of nursing in caring for terminally ills' life: a phenomenological study. Rev. Esc. Enferm USP [Internet]. $2014 \mathrm{Dez}$; [Cited 2016 Out 22]; 48(1):34-40. Available from: $\mathrm{http} / / / \mathrm{dx}$.doi.org/10.1590/S0080-623420140000100004

16. Santos EM, Sales SA. Familiares enlutados: Compreensão fenomenológica existencial de suas vivências. Texto Contexto Enferm. [Internet] 2011. [Cited 2019 Out 07]; 20 (spe):214-222. Available from: http:// dx.doi.org/10.1590/S0104-07072011000500027.

17. Sales CA, Almeida CSL de, Wakiuchi J, Piolli KC, Reticena K. I survived cancer: phenomenological analysis of the survivors' language. Texto Contexto Enferm. [Internet]. 2014 Out/Dez; [Cited 2016 Out 18]; 23(4):880-8. Available from: http://dx.doi.org/10.1590/010407072014002050013

18. Menezes NNT, Schulz VL, Peres RS. Impacto psicológico do diagnóstico do câncer de mama: um estudo a partir dos relatos de pacientes em um grupo de apoio. Estud. psicol. [Internet] 2012 Mai/Ago; [Cited 2016 Out 15]; 17(2):233-40. Available from: http://dx.doi.org/10.1590/S1413$-294 X 2012000200006$

19. Oliveira MFV, Carraro TE. Cuidado em Heidegger: uma possibilidade ontológica para enfermagem. Rev. Bras. Enferm. [Internet] $2011 \mathrm{Mar} /$ Apr; [Cited 2016 Out 18]; 64(2):376-380. Available from: http://dx.doi. org/10.1590/S0034-71672011000200025

20. Cardinalli, IE. Heidegger: $O$ estudo dos fenômenos humanos baseados na existência humana como ser-aí (Dasein). Psicologia USP [Internet] 2015 Out; [Cited 2019 Set 16]; 26(2):249-258. Available from: http:// dx.doi.org/10.1590/0103-656420135013

21. Guimarães $O O$, Dias CC. A angústia de (ser) e sua interface com a existência e a morte. Psicologia e Saúde em Debate [Internet]. 2017 Jan; [Cited 2019 Set 16]; 2(2): 42-57. Available from: https://doi. org/10.22289/2446-922X.V2N2A3

22. Ferreira VS, Raminelli $\mathrm{O}$. O olhar do paciente oncológico em relação a sua terminalidade: ponto de vista psicológico. Rev. SBPH [Internet]. 2012 Jan/Jun; [Cited 2017 Out 06]; 15(1): 101-113. Available from: http:// pepsic.bvsalud.org/pdf/rsbph/v15n1/v15n1a07.pdf

23. Fornazari SA, Ferreira RER. Religiosidade/espiritualidade em pacientes oncológicos: qualidade de vida e saúde. Psicol. teor. pesquisa [Internet]. 2010 Abr/Jun; [Cited 2016 Out 15];26(2):265-72. Available from: http:// dx.doi.org/10.1590/S0102-37722010000200008

24. Ferreira PC, Wakiuchi J, Baldissera VDA, Sales CA. Existential feelings expressed by users of the house of support for people with cancer. Esc. Anna Nery [Internet]. 2015 Jan/Mar; [Cited 2016 out 15]; 19(1):66-72. Available from: http://dx.doi.org/10.5935/1414-8145.20150009 